\title{
CRITICAL-COLLABORATIVE LANGUAGE EDUCATION THROUGH ENGLISH: AN EXPERIENCE WITH YOUTH AND ADULT EDUCATION STUDENTS
}

\section{EDUCAÇÃO LINGUÍSTICA CRÍTICO-COLABORATIVA POR MEIO DO INGLÊS: UMA EXPERIÊNCIA COM ESTUDANTES DA EDUCAÇÃO DE JOVENS E ADULTOS}

\author{
Ricardo Regis de Almeida* \\ Neuda Alves do Lago** \\ Francisco José Quaresma de Figueiredo***
}

\begin{abstract}
This study takes a cue from the biography of Maya Angelou and aims to intertwine her life experiences to a critical-collaborative language education through English approach. To reach our goal, a group of four Youth and Adult Education (YAE) students departed from Instituto Federal de Goiás (IFG) and metaphorically went to the U.S.A. through the story of the black woman aforementioned. Our reflections during this adventure were drawn on the works of many scholars, such as Almeida (2017); Figueiredo (2008, 2018); Figueiredo \& Lago (2018); Lago \& Cintra (2016); Magalhães (2014); Morrison (1975); Pessoa (2014); Rosa \& Flores (2017); Scarcella \& Oxford (1992), among others. We find it paramount to mention that our problematizations also stemmed from our very own experiences with the study participants as well as our personal narratives and struggles against racism, sexism, poverty and other types of prejudice in our classes. Our empirical material was generated through an open-ended questionnaire, the letters the students wrote to themselves in class, and the discussions carried out in a yarning circle about an experience the study participants had with students from three first-year high school integrated courses - Foreign Trade, Construction and Chemistry. We conclude that this investigation allowed us and the study participants to reflect upon and rethink our opinions about our bodies, complexion, and the very process of language education through English. Keywords: Maya Angelou; critical-collaborative language education through English; Youth and adult education.
\end{abstract}

\section{RESUMO}

Este estudo é inspirado na biografia de Maya Angelou e visa entrelaçar suas experiências de vida a uma abordagem de educação linguística crítico-colaborativa por meio do inglês. Para alcançar nosso objetivo, um grupo de quatro estudantes da modalidade Educação de Jovens e Adultos (EJA) partiu do Instituto Federal de Goiás (IFG) e foi metaforicamente para os EUA através da história da mulher negra mencionada acima. Nossas reflexões durante essa aventura foram baseadas nas obras de diversos/ as autores/as, tais como Almeida (2017); Figueiredo (2008, 2018); Figueiredo e Lago (2018); Lago e Cintra (2016); Magalhães (2014); Morrison (1975); Pessoa (2014); Rosa e Flores (2017); Scarcella e Oxford (1992), entre outros/as. Achamos fundamental mencionar, ainda, que as problematizações aqui presentes também se originaram das nossas próprias vivências: como as narrativas pessoais das participantes do estudo e as nossas próprias histórias de luta contra o racismo, o machismo, a pobreza e outros tipos de preconceito em nossas aulas. O material empírico foi gerado a partir de um questionário aberto, das cartas que as alunas escreveram para si mesmas nas aulas e das discussões realizadas em uma roda de conversa sobre uma experiência que as participantes do estudo tiveram com estudantes de três cursos integrados do primeiro ano do Ensino Médio - Comércio Exterior, Edificações e Química. Concluímos que esta investigação permitiu que as participantes do estudo assim como nós refletíssemos e repensássemos as nossas verdades sobre os nossos corpos, pele e sobre o próprio processo de educação linguística em língua inglesa.

Palavras-chave: Maya Angelou; educação linguística crítico-colaborativa em inglês; Educação de Jovens e Adultos.

\section{DEAR READER ${ }^{1}$}

We are eager to share some of the (un)learning processes experienced by each one of us throughout this journey. The use of the pronoun we does not only imply the collaboration among the authors of this paper. More than that, we acknowledge the relevance of Maya Angelou's ${ }^{2}$ life story and the four female students who overtly engaged

* Programa de Pós-Graduação em Letras e Linguística da Universidade Federal de Goiás (UFG), Goiânia, GO, Brasil. ricardoregisalmeida@ gmail.com

Orcid: https://orcid.org/0000-0001-9049-8401

** Universidade Federal de Goiás (UFG), Goiânia, GO, Brasil.neudalago@ufg.br Orcid: https://orcid.org/0000-0003-0887-9083

***Universidade Federal de Goiás (UFG), Goiânia, GO, Brasil. franciscofigueiredo@ufg.br Orcid: https://orcid.org/0000-0002-5936-1578

1. This paper will be written in the form of a letter considering that Maya Angelou's letter to her younger self was the source of inspiration for this work.

2. Marguerite Annie Johnson Angelou (April 4, 1928 - May 28, 2014), known as Maya Angelou, was an African-American woman, poet, author, professor, actress, screenwriter, dancer, mother, civil rights activist and a brave black woman who insisted on fighting against racism and social inequalities in the United States of America. 
in this trip with us shedding light and problematizing distinct aspects of the collaborative and critical approaches ${ }^{3}$ to language education through English. We departed from a very specific place, a group of YAE ${ }^{4}$ students from Instituto Federal de Goiás (IFG), situated in a city near Goiânia - the capital of the state of Goiás, and metaphorically went to the other side of the Americas, the United States of America, through the story of the African-American woman aforementioned.

Maya Angelou was not only an inspiration to the English classes here presented and problematized. Her struggles were examples to the students and to their teacher (the first author of this paper), who were both tired of looking for people who fight like us, cry like us, are hungry for racial and social justice like us, but rarely exist in English classes or textbooks. This woman also represented liberation in those classes. Liberation from the racism suffered by many of those students. Liberation from the domestic violence marked on some of those students' black skin. Liberation from the psychological violence imbued in their ways of looking at themselves and the world around them. And liberation from the myth that those students could never learn another language at their age. Maya Angelou's personal records came out as a possibility to reinvent what the English language meant to those learners and their teacher. From that moment on, learning a language would never again mean only acquiring structures, expanding vocabulary, improving pronunciation or working on spelling. It significantly became a possibility to, through the English classes, release from the pain felt by many of those women sitting on their classroom chairs.

Having recognized the importance of the woman who inspired this work, we remind the reader that, among our contradictory and conflicting purposes along the route, our biggest aim in this paper is to take a cue from the biography of Maya Angelou and intertwine her life experiences to a critical-collaborative language education through English. Most importantly, we put our efforts together to bring her narrative close to ours. In order to reach our goal, the first author, as their teacher in that opportunity, arranged the classes itinerary in the form of a didactic route (SABOTA, 2017). Firstly, the students watched and discussed an autobiography on Netflix entitled Maya Angelou and still I rise. Secondly, they researched some of the personal records of the black people who appeared in the film and, afterwards, discussed their findings with their fellow classmates and the teacher in class. Thirdly, they read and reinterpreted in Portuguese a letter written by Ms Angelou addressed to her younger self. Fourthly, the students also wrote a letter to themselves describing their experiences during the classes about Maya Angelou. Lastly, they went on an adventure with their teacher and shared their newfound knowledge about the lessons with other three firstyear high school integrated courses - Foreign Trade, Construction and Chemistry ${ }^{5}$.

During our venture, we (mis) understood many aspects of the English language. For instance, some of us thought English was chiefly spoken by the white middle-class in the U.S.A., while others conceived English as a complex language to be learned. Almost everybody believed that learning English in Brazilian public schools was synonymous with understanding the verb to $b e_{;}$and it was practically impossible to imagine we could learn English from an African-American woman's life story. Bearing these thoughts in mind, we, with the aid of Maya Angelou, along with the four female students mentioned earlier and some additional scholars (ALMEIDA, 2017; FIGUEIREDO, 2008, 2018; FIGUEIREDO; LAGO, 2018; LAGO; CINTRA, 2016; MAGALHÃES, 2014; MORRISON, 1975; PESSOA, 2014; ROSA; FLORES, 2017; SCARCELLA; OXFORD, 1992, among others), decided to question the representations mentioned in the previous paragraph and propose different ones.

In the beginning, we found in the collaborative language learning a means to co-construct knowledge among ourselves and strengthen our bonds (FIGUEIREDO, 2018) by (un)learning or attempting to (un)learn the myths mentioned in the previous paragraph. In the middle of our trip, we aligned our conceptions to the ones advocated by the critical language learning. We reflected upon categories such as race/racism and the English language itself, and attentively listened to the stories Maya Angelou shared with us along the way. It is imperative to mention that we do not want to juxtapose or hierarchize these two different approaches considering that both, each one in a particular

3. We draw on Pessoa's (2014) work to claim that, by "approach", we mean the way we do things. In this work, it relates to how the participants understood and implemented critical-collaborative learning throughout the discussions presented here.

4. According to Vasques, Anjos and Souza (2019), Youth and Adult Education (YAE) has its history rooted in exclusions and denial of rights similar to the history of the Brazilian people and their social situation still experienced by many in this subject. Education, seen as a privilege of the elite, left the blacks, the poor, the women, the disabled and all the socially forgotten, also excluded and outlawed from the schooling process for centuries. The scholars also state that reflecting upon YAE requires understanding its specific purposes and an approximation of the popular school democratic principles defended by Paulo Freire. In line with the authors' arguments, we believe that YAE should be understood, first and foremost, as a political act in which the students read their realities first and then learn how to read the written words which permeate society.

5. In Portuguese, they correspond to Comércio Exterior, Edificações e Química. 
fashion, contributed to our travel purposes. Therefore, we decided to adopt the term critical-collaborative in this work since we advocate for a teaching praxis that considers both critical and collaborative aspects equally important for the language education process.

Later on that day, we stopped and took a deep look at the people around us, bringing our attention to some very peculiar characteristics of our trip and the individuals close to us. Having rested a while, we continued - crying sometimes and laughing most of the time - and shared our viewpoints on the episodes regarding the English language and the racist and discriminatory acts some of us had experienced (directly or indirectly) in the course of our lives. In that moment, we attempted to link our four travel companions' stories to the ones we had heard and read of Maya Angelou. Finally, we arrived at our destination and shared the pros and cons of our trip and invited other travellers to engage in adventures such as ours. Shall we now take a look at our itinerary in a detailed way?

\section{WE WOULD LIKE TO SUGGEST THAT "TOGETHER WE STAND, DIVIDED WE FALL"}

In this part of our travel, we recognized the presence of each sojourner around us. More than that, we understood that, alone, we would not have achieved half of the goals we had already accomplished with them. The first author of this paper, as their teacher, also realized that his tutelage alone was not enough to guide them through. He needed other theorists to engage with him in that process ${ }^{6}$.

Figueiredo (2018, p. 14) states that "collaborative learning is a constructivist philosophical approach, which, in broad lines, refers to educational situations where two or more people learn or attempt to learn something together by means of interaction" ${ }^{\prime \prime}$. Interaction is the aspect which characterizes this investigation. In regard to the language classroom, the author contends that interaction is a set of opportunities created for the students to communicate among themselves or with the teacher in the language they are learning. Likewise, Scarcella and Oxford (1992, p. 60) underscore some benefits of cooperation ${ }^{8}$ in the classroom such as "higher self-esteem, increased confidence and enjoyment; more respect for the teacher, the school, and the subject; greater and more rapid achievement; use of higher level cognitive strategies; decreased prejudice; and increased altruism and mutual concern".

Magalhães (2014, p. 24), based on Vygotsky's sociocultural theory, posits Collaboration "as fundamental to the process by which we become who we are through socio-historical-culturally situated relationships with others". She continues to state that this process takes part in "a complex relationship between the individual and the collective that involves an active participation in the transformation of the self, the other and the world". The scholar concludes, ergo, that collaboration is intrinsically related to the concept of contradiction, considering that it involves relations between the participants with different social, cultural, historical, and political formations.

According to O’Donnel and Dansereau (1992), as cited in Figueiredo and Lago (2018, p. 204), "the processes of collaborative learning, such as peer correction, are profoundly embedded in an affective context", that is to say, affective factors, among which we can mention success expectation, subjective values, attitudes and beliefs towards themselves as learners, motivation, anxiety etc., are equally important to the students' learning process. Furthermore, collaborative learning has been considered an important component in the process of increasing students' selfesteem towards the school and the learning process. Yet, it is deemed to be favourable to learners of all different proficiency levels (FIGUEIREDO; LAGO, 2018).

\section{WHAT ABOUT QUESTIONING THE WOR(L)D AROUND US?}

In this part of the trip, we felt a great need to question the wor(l)d around us. After all, we had seen, through Maya Angelou's life story, that several inequalities are perpetuated by means of race/racism, social class, gender, science and language itself (ALMEIDA, 2017; PENNYCOOK, 2004; URZÊDA-FREITAS, 2012, 2018). Morrison $(1975$, p. 7$)$, for instance, contends that:

6. Although we underscore the importance of getting the participants involved in our study, we find it vital to point out that sometimes the teacher's voice excelled theirs, and his opinions turned out to be the single truth for them even though he did not encourage that.

7. This and all the other excerpts originally written in Portuguese were translated into English by the authors of this paper.

8. Some authors understand Cooperation and Collaboration as distinct concepts (for a deeper understanding of these differences, read Figueiredo (2018)). We, however, advocate that the benefits mentioned by the authors are favorable to all kinds of teaching/learning approaches. 
the function, the very serious function of racism is distraction. It keeps you from doing your work. It keeps you explaining, over and over again, your reason for being. Somebody says you have no language, so you spend twenty years proving that you do. Somebody says your head isn't shaped properly, so you have scientists working on the fact that it is. Somebody says you have no art, so you dredge that up. Somebody says you have no kingdoms, so you dredge that up. None of that is necessary. There will always be one more thing.

Taking this cue from Morison (1975), Rosa and Flores (2017, p. 2) assert that there is a "continued rearticulation of colonial distinctions between Europeanness and non-Europeanness - and, by extension, whiteness and nonwhiteness". The authors claim that the two central components of the European colonial formation of modernity were "the construction and naturalization of the concept of race along with the construction and naturalization of languages as bounded and separate objects associated with particular racial groups" (ROSA; FLORES, 2017, p. 3).

Morrison's words contributed to our understanding that, sometimes, we were also getting distracted from doing our work. At the beginning of our journey, most of the students believed it was impossible to learn a new language assuming they did not even know Portuguese. What is even worse, they spent time proving to themselves and to their teacher they did not speak Portuguese, their own language, well. Were these students captured by the colonial project of understanding language, social class, race and other invented categories as bounded and separate objects? Why did they believe they would never learn English? Would this assumption be somewhat related to their gender, age, social class, race, and the fact they were YAE students at the time of this research? Would it be because the European project of modernity mentioned by Rosa and Flores (2017) succeeded in making these students see themselves as languageless beings? ${ }^{9}$

Alongside the perspective of questioning the wor(1)d around us, Pennycook (2004) advocates for a problematizing practice in our critical work, i.e., an attitude of inquiring our ways of understanding the human being, the nature and the objects around us in search of other possibilities that, according to Almeida (2017, p. 18), "allow the existence, whether it is liquid or rarefied, of other identities and practices that extrapolate the reductionist/binary notion responsible for segmenting and neglecting other ways of experiencing the social world".

In a continuing teacher education course offered by Lago and Cintra $(2016$, p. 139), one of the modules entitled Critical Language Learning sought to "promote discussions and debates aimed at developing the critical capacity of each teacher, using world and linguistic knowledge as social practice". To do that, the participants read and held discussions about teacher education, critical pedagogy, critical theory, and teaching as transgression. Some themes problematized by the group were sexuality, racism, child labour, teen pregnancy, homophobia, and others.

Lago and Cintra's course and other studies (HOELZLE, 2016; SILVESTRE, 2017; URZÊDA-FREITAS, 2012, 2018) are examples of how applied linguists in Brazil have worked on the disarticulation of hegemonic, racist and segregationist discourses within and outside the academy. Regarding critical language teacher education, Pessoa (2014, p. 356) avouches that it aims at "relating micro-relations of applied linguistics to macrorelations of social reality and tries to problematize not only the inequitable relationships of power and social reality but also language neutrality".

In summary, the discussions presented in this section show evidence that it is necessary to inquire and reinvent the wor $(1) \mathrm{d}$ around us. It was by means of problematization that the theorists mentioned herein and the participants of this study were capable of looking at language from a critical perspective, and not only as an instrument meant to merely transmit messages. More than this, it was made possible for these students to understand that coloniality and whiteness are rearticulated in unimaginable ways. This rearticulation should not prevent them from attempting to look at themselves and at others in a critical way, but rather understand that giving up is not an alternative. Problematizing and reinventing the wor $(1) \mathrm{d}$ is!

\section{THE WAY WE SEE OURSELVES}

This is the moment we look around and bring our attention to some features that constitute each one of us. Bearing in mind our purpose of discussing the biography of Maya Angelou and intertwining her life experiences with a critical-collaborative approach to the learning of English, we take advantage of this deep introspective instant to (un)learn some aspects of our work and its participants.

9. These and other questions which will appear across this study do not need an immediate answer. They have the purpose to help us think about the reasons why many students usually give up on learning other languages and what can be done in order to have them continue and engage themselves in the learning process. 
It is characterized as a qualitative case study considering that we only had a few participants ${ }^{10}$ engaged in this trip with us. André $(1995$, p. 31) contends that "a case study emphasizes the knowledge of the particular. This does not, however, prevent the researcher from being aware of his/her context and its interrelations with an organic whole, and its dynamics as a process, a unity in action". Our four travellers are referred to in this work under pseudonyms, to protect their identities.

Luana, Zuy, Angel and Mariana are the women who took the challenge and embarked on this trip with us. Before addressing them properly, we find it pertinent to present our research sources for all the information discussed in this paper. They were: an open-ended questionnaire taken at the end of the lessons about Maya Angelou, the letters the students wrote to themselves, and a yarning circle ${ }^{11}$ wherein the students and the teacher talked about their (un)learning experiences throughout our journey. Following are short descriptions of each participant's profile and their relationship with English according to their answers in the questionnaires.

Luana is 28 years old and considers herself a black woman ${ }^{12}$. She does not relate to English very much; however, she tries her best to learn the language because, as she reported in her questionnaire, it is one of the most spoken languages around the globe. Zuy is 43 years old and considers herself a white woman. She affirmed that she had never had an opportunity to understand the purpose of her English classes before. According to her, now she can listen and read in English better than before. Angel is 42 years old and considers herself a mulatta. She used to think it was impossible to learn another language. However, when she started to learn new words in English, she fell in love with the language despite her supposed lack of proficiency. Mariana is also 42 years old and identifies herself as a white woman. She thinks her relationship with English could be better. She avows that she is in touch with the language only inside the classroom, but she tries to make the most of these moments.

As suggested by Urzêda-Freitas (2018, p. 92), the crystallization of the empirical material "opens up more space for the constructions of the researcher, since it presents a multitude of possibilities of analysis and understanding of information, including presupposing the intermingling of different forms of writing". The crystallization of our empirical material, ergo, allowed us to think of and propose three different sections to present our empirical material and discuss it: 1) learning English through Maya Angelou's life story; 2) collaborative learning experiences with students from the Construction, Foreign Trade and Chemistry courses; and 3) a letter to myself: who I am today and what Maya Angelou and English classes have to do with it. Having done that, we selected and partially transcribed the empirical material which established a dialogue with the categories previously mentioned and organized it accordingly. In the following three sections, you may fasten your seatbelts because you are about to take off on a very emotional journey.

\section{LEARNING ENGLISH THROUGH MAYA ANGELOU'S LIFE STORY}

In this part, the students stated their responses to studying Maya Angelou's biodata and how it affected their learning process. Although Literature had not been the main focus of our paper, we could not deny how important it was for the participants' process of learning English and revisiting their wor(l)ds. In a study carried out by Lago and Cintra (2016), they conclude that the students who participated in the research could profit significantly from the contact with the foreign literary text despite several obstacles represented by the act of reading literature in a foreign language. By the same token, we argue that the participants of this study benefitted from the contact with Maya

10. It is indispensable to report that, although only four students were chosen to be part of this study, more than ten students embarked on this trip with us. Unfortunately, they did not have the chance to participate in all the activities but were able to attend part of them.

11. The yarning circle happened days after the four study participants took part in three other classes and shared a bit of their life experiences with students from three first-year high school integrated courses - Construction, Foreign Trade and Chemistry. This initiative was given life because their English teacher, the first author of this paper, saw an opportunity to also bring Maya Angelou's biography to the students from the courses aforesaid and intertwine the African-American author's life experiences to those shared by the four women participating in this study. It was a moment in which the younger students could see that there were other strong women just like Maya Angelou right next to them and studying in the same institution. After all, those four grown women sitting in front of them had given themselves a second chance to finish their studies and find other ways to make meaning of their lives. Having said that, we believe that the experience of those four women with the Construction, Foreign Trade and Chemistry students and the conversations carried out in our yarning circle were much more than a moment of exchanging experiences. It was an instant in which the stories of resistance and re-existence shared by those four women became real possibilities for them and for those younger students to act differently in the social world.

12. Before the classes about Maya Angelou, this student did not identify herself as black. She would say she is brunette. In our opinion, it is a strategy commonly used to distance oneself from the black identity. 
Angelou's life story, through her poems and the letter to her younger self read and reinterpreted in class. According to Mariana, she learned the story of Maya Angelou through English and learned the language through the biography of the author in a very profitable manner ${ }^{13}$ :

(Excerpt 1) The English classes in which I studied the life of Maya Angelou were really a lot of help for me. These were moments of great reflection and learning. Not only did I get to know the exciting story of Maya Angelou and the lessons, but I also learned about the English language. To be honest, I learned about Maya Angelou through the English language and I learned English with the story of Maya Angelou. In my opinion, one completed the other and I enjoyed it to the fullest. (Mariana - Questionnaire).

As seen in the testimony above, the classes about Maya Angelou were moments of great reflection and learning. Mariana's words demonstrate that she did two things at the same time in class: learned from Maya Angelou's life experiences and studied English. As Okazaki (2005, p. 181) argues, "it is crucial that the content be immediate and meaningful to students so that they become aware of both the reproductive nature and the possibility of resistance to problematic content". When the teacher perceived that some individuals understood English as a distant and decontextualized subject, he realized he had to work differently considering that the students' beliefs towards English were leading them to indifference and apathy in class. The documentary Maya Angelou and still I rise appeared to be an immediate opportunity to bring meaningful content to those students. Maya Angelou's life story seemed close to their reality and the teacher saw that as a possibility to approach English in a collaborative and critical way. So, that is what he did - he decided to plan some of his lessons contemplating Maya Angelou's experiences.

Zuy was clearly touched by Maya Angelou’s life story. She cried when she talked about the classes and shared what she was studying with her daughter. Yet, she reported that going to school was similar to entering a new world since she was never able to find stories such as Ms Angelou's on the internet:

(Excerpt 2) Maya is amazing! As I was talking to my daughter, I mentioned that when we start studying, we start to see. (I do not know where the teachers find these stories) It's because we live in our small world, and when we go to school, it seems that we are in another world. For example, when you get to know different people, people who fight, people who run after their dreams, we begin to see things differently as well. Then, you wonder, why do I never find stories (like Maya Angelou's) when I surf the web? Maya was... (crying) an inspiration to me. It is like... what have you done with your life so far? You know when I mentioned that standing tree in the questionnaire, that is how I feel. I am like a mirror, like that beautiful shade tree, full of leaves and that supports everyone, supports everything. But you are stuck there, your life is standing still. That is how I see myself. Why, even in the face of difficulties, do you not move forward? Why do you help the people around you, your family, and you do not move on with your life? (Zuy - Yarning circle).

Zuy's attitude of examining herself through her English classes reveals to us one of the principles of critical applied linguistics, which is self-reflexivity (MOITA LOPES, 2006; PENNYCOOK, 2001, 2004, 2012). We believe this participant took hold of Maya Angelou's experiences and brought the author's narrative close to hers. Although her self-questionings seem a bit disheartening, we find them examples of how the classes helped her understand that she could not continue being the tree she mentioned - taking care of everybody else and feeling helpless on the inside. Concerning collaboration, Magalhães (2014, p. 24) understands it as "a complex relationship between the individual and the collective that involves an active participation in the transformation of the self, the other and the world". This concept of collaboration contributes to the realization that the classes echoed and touched other people through the act of exchanging experiences. Therefore, the attitude of sharing her anguish with her daughter might have helped both mother and daughter re-examine their attitudes towards each other, and maybe, helped to reach other family members. Who knows? Maybe the tree will change the way she sees herself.

In Angel's words, the classes about Maya Angelou encouraged her to look up new English words in the dictionary, which she confessed she did not use to do frequently:

(Excerpt 3) The lessons were quite instructive because they were a unique moment where words that I already knew and others that I had never seen came together. Those moments made me want to look them up in a dictionary, which, I must confess, I did

13. As proposed by Sousa et al. (2019, p. 265) in their paper, "the linguistic repertoire used for transcriptions of the utterances in Portuguese are an approximation of the standard written language". Taking this cue from the authors, all the excerpts that are the students' answers for the questionnaire and their comments made in the yarning circle were translated by us. 
not do before. However, when I saw that woman speaking, I had a great curiosity to learn more. Her story was an inspiration to the English language. (Angel - Questionnaire).

As it is possible to observe in the excerpt, the participant's curiosity about English words increased due to the fact that Maya Angelou's story served as an inspiration to her. As reported by Sabota (2018, p. 101), "reading is interactive and transcendent, and it is not just about the decoding of the text: it seeks to go beyond". Angel's testimony is paramount to this study considering that the classes were meant to be more than just translation or the learning of new words in English through the story of Ms Angelou. We deeply wanted her story to transcend and go beyond our readings and talks in class. We had high hopes that the author's life experiences would serve as a driving force for those students to learn English collaboratively and "to engage with questions of power and inequality and, more important, to problematize how language perpetuates inequitable social relations" (PESSOA, 2014, p. 357).

Pessoa's quote and our aforementioned hope echoed in Luana's excerpt when she argued that prejudice and racism are pervasive, even in the United States of America, a country that is usually idolized and seen as an example of democracy by many Brazilians. As she put it:

(Excerpt 4) The classes were very interesting because when people refer to the United States, they think of white people, with blue or green eyes and very successful. In class, we studied the history of Maya Angelou and learned that it is not quite like this. Prejudice and discrimination exist everywhere. However, Maya Angelou struggled, gained space, read many books, wrote books, had several professions, and had recognition. With all of this, I've changed my way of thinking. (Luana - Questionnaire).

The transformative stance is one of the principles of critical language learning (PENNYCOOK, 2001). Notwithstanding, Urzêda-Freitas (2012, p. 80, emphasis in the original) argues that "before promoting this change, it is necessary to unveil the various forms of prejudice and discrimination, as well as to recognize the weight of their adversities in the social sphere". Luana's excerpt shows how she changed her mind after she had understood how prejudice and discrimination are perpetuated in society. Maya Angelou's story of resistance demonstrated that, despite the difficulties and barriers imposed by whiteness upon her life, she was able to contest and fight against it until the very last minute of her existence. Luana's linguistic changes in the course of our lessons demonstrate that she found in this black woman's trajectory of life a means to resist the violence she has suffered in her own life for also being a black woman, proving that language is intrinsically connected with people and society (PESSOA, 2014).

\section{COLLABORATIVE LEARNING EXPERIENCES WITH STUDENTS FROM THE CONSTRUCTION, FOREIGN TRADE AND CHEMISTRY COURSES}

Studying Maya Angelou's biography was the starting point that we could use to spread her words around the campus. After almost a month of having classes about Ms Angelou, I invited the whole YAE group to participate in an English class with high school students from the Construction, Foreign Trade and Chemistry courses. As referred to earlier, the four women participating in this study were the ones who engaged in this adventure with their English teacher and shared what they learned with those students. The latter were also investigating Ms Angelou's achievements and had to deliver a presentation about their findings. To do so, the apprentices - in groups, pairs, or individually - had to use their imagination and creativity to get the audience involved. Their presentations could be either in Portuguese or in English considering that most of them were first-year English learners.

The four YAE students mentioned that they had their lives changed. Although at first glance some of them seemed a bit reluctant to the idea of being in a class with teenagers, they all underscored different aspects of what that moment personally meant to them, and how the presentations encouraged cooperation and collaboration among those students. All this can be seen in Angel's and Luana's passages below:

(Excerpt 5) In my case, I almost came to the point of telling you I was not going (to participate in the classes), but since I had already made a commitment to you, I decided to go. To tell you the truth, I got into a panic, but it turned out to be a new and dynamic experience because when I entered there and I saw that they were so involved, each one with their talent, with their way of interpreting.... student recited a poem, another one made a paper bird in a cage, a schoolgirl made an origami, and one of them performed in class. They were really dynamic. They did not follow a model. Each one used what they had at their disposal. They felt inspired and did what they had to do. It was so beautiful because they respected each other... they got together to 
help their colleagues and that was beautiful because that is when you see there is hope. Because from the moment you help your colleague, you are encouraging him/her and this is beautiful to see [...]. (Angel - Yarning circle).

(Excerpt 6) It was great for me to share what I had learned and to listen to the students speak with so much respect and enthusiasm about the life and history of Maya Angelou. When I left school and went back home, I was very happy because I learned a lot from the students. I could see how much they got involved and worked hard to deliver good presentations. All of them delivered great presentations. Overall, it was simply an enriching and incredible experience. I was overwhelmed, and I will take what I have learned in those classes throughout my entire life. (Luana-Questionnaire).

Drawing on the works of Crandall (1999) and Graith (2002), Figueiredo (2008, p. 122) asserts that in collaborative classrooms, students "have the chance to learn from their peers and to teach them. By working together, they have the chance to notice what they still have to learn, and they also have the opportunity to develop social, cognitive and affective skills". In like manner, Angel goes on to say that, when she partook in those classes with other teenagers, she could perceive they truly worked together, which proved to her that there is still hope for the future. She seemed touched by the way students delivered their presentations. According to her, they were really dynamic and did not follow a pattern in that moment. Her words acquiesced with what Figueiredo $(2018$, p. 26) states about how tasks are performed in collaborative classroom settings. As he puts it, "the tasks of group members are usually unstructured: their roles are defined as the task occurs". By the same token, Luana felt like those classes were a moment for life. Figueiredo and Lago (2018, p. 207, emphasis in the original) affirm that engaging students in tasks that involve others is essential given that "self-esteem will grow as students forget their own self-esteem, directing their attention away from the self". Luana's self-esteem appears to have had a boost after she participated in those classes with other students. As she stated during our yarning circle, it was a unique experience because the students applauded her in class, which made her feel important.

Mariana's testimony shows how impressed she was by the students' engagement and excitement in the presentations. Moreover, she asserts that Maya Angelou's life-changing experiences honestly meant something to those learners:

(Excerpt 7) Attending a class with students from the Chemistry, Foreign Trade and Construction courses was one of the most exciting and challenging experiences I have ever had in my life. Seeing students so young and so excited about an English language class and Maya Angelou's life story, just as I was. I did not believe it was possible because they were so young. How is it possible that they were so interested in a story of a black writer who suffered so much prejudice and many horrible things she endured in life? However, she surpassed all those bad things showing that when you want something, you have to fight for it even if everybody is against you. Although they were young, they gave their best, just like I did (in my classes). Maya's overcoming history was as meaningful to them as it was to me. It was truly an unforgettable and productive experience for my life. (Mariana - Questionnaire).

Zuy, in turn, reflects on how teenagers are seen by society and makes a claim to people who fool themselves when they assume that adolescents only listen to music and do not think appropriately:

(Excerpt 8) As I have already said, young people are very inspiring. They have a very different way of thinking. It is a shame people do not listen to young people today. They think it is only a phase or that they do not know anything. They know indeed! They are always up to date with what is happening in the world, with what they want to do in the future. People fool themselves when they say that teenagers just want to listen to music or that they do not think. They have their own way of thinking. They dream of building something better for them. I think this dream of building something should not die because the world would be better. In class, I was thrilled because, as I said, those students have dreams and they are deeply connected with what is happening around the world. One example of it is how each one of them presented Maya's biography. (Zuy - Yarning circle).

As we can infer from Mariana's words (excerpt 7), it was a surprise to see those adolescents so interested in the story of a black woman who struggled against racism and segregation. On the other hand, Zuy (excerpt 8 ) points out that young learners are very inspiring and that they should not be discredited by society. Although there are good prima facie reasons to believe that Mariana and Zuy have antagonistic standpoints about young learners, we understand that both testimonies go beyond this possibility and illustrate how collaboration can help students not only learn from each other but also undermine solidified beliefs such as the ones problematized by Zuy. 


\section{A LETTER TO MYSELF: WHO I AM TODAY AND WHAT MAYA ANGELOU AND THE ENGLISH CLASSES HAVE TO DO WITH IT}

In this last moment of reflections upon Maya Angelou and the English classes about her, the students were asked to write a letter to themselves considering what the English classes about Maya Angelou meant to them. This is what they told themselves ${ }^{14}$ :

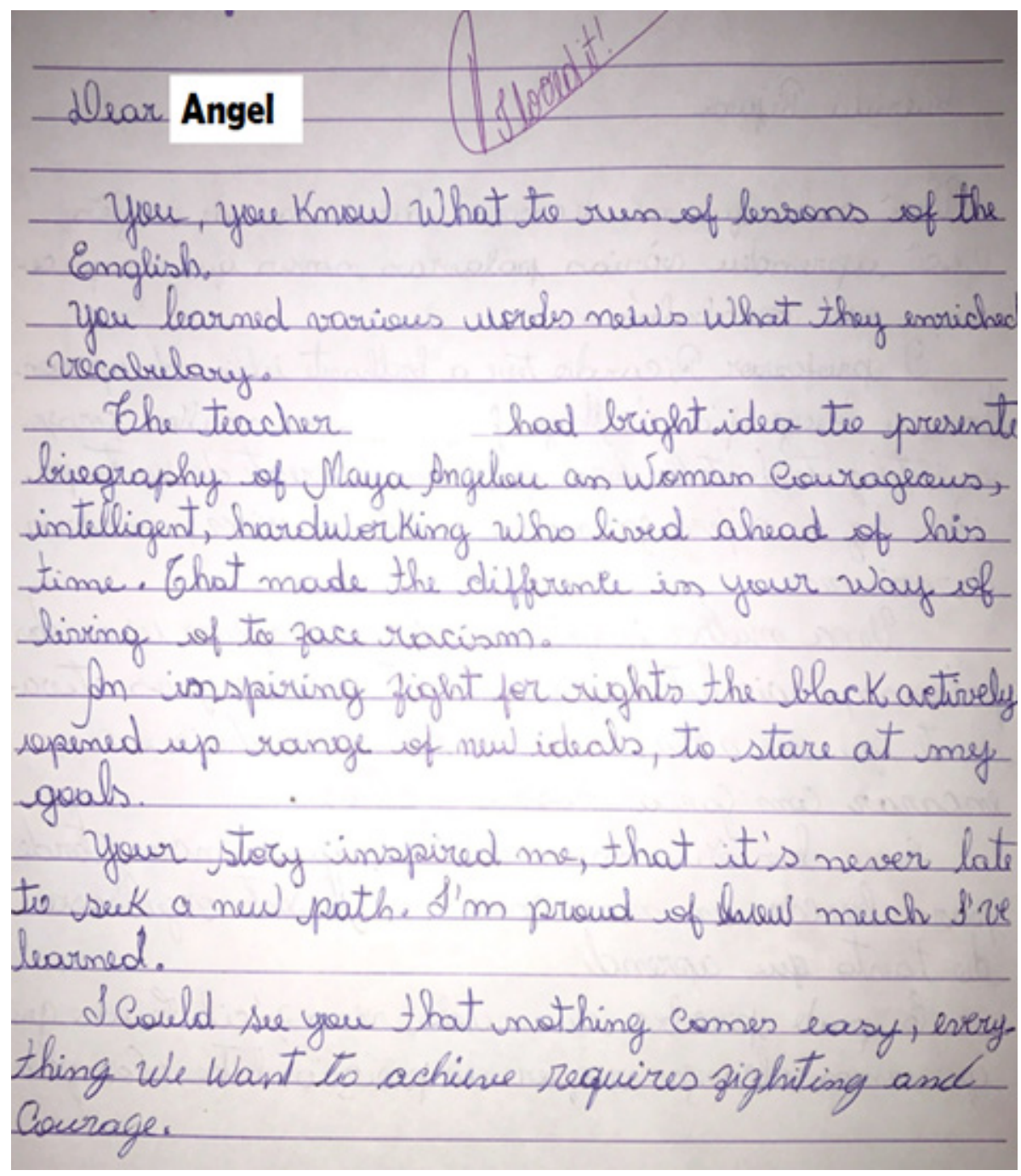

Figure 1. Angel's letter to herself regarding the classes about Maya Angelou

Dear Angel,

You, you know what to run of lessons of the English.

You learned various words news what they enriched vocabulary.

The teacher had bright idea to presente biography of Maya Angelou an woman courageous, intelligent, hardworking who lived ahead of his time. That made the difference in your way of living of to face racism.

An inspiring fight for rights the black actively opened up range of new ideals, to stare at my goals.

Your story inspired me, that it's never late to seek a new path. I'm proud of how much l've learned.

I could see you that nothing comes easy, everything we want to achieve requires fighting and courage.

\footnotetext{
14. We did not want to change a single word of what the students wrote in their letters. Instead of checking the standard written language in their narratives, we opted to genuinely listen to them and see what they were able to learn from the classes, especially the use of the English language in a written production. Bearing it in mind, we invite you, dear reader, to engage in the reading of these letters focusing only on the rich experiences these women had to share.
} 


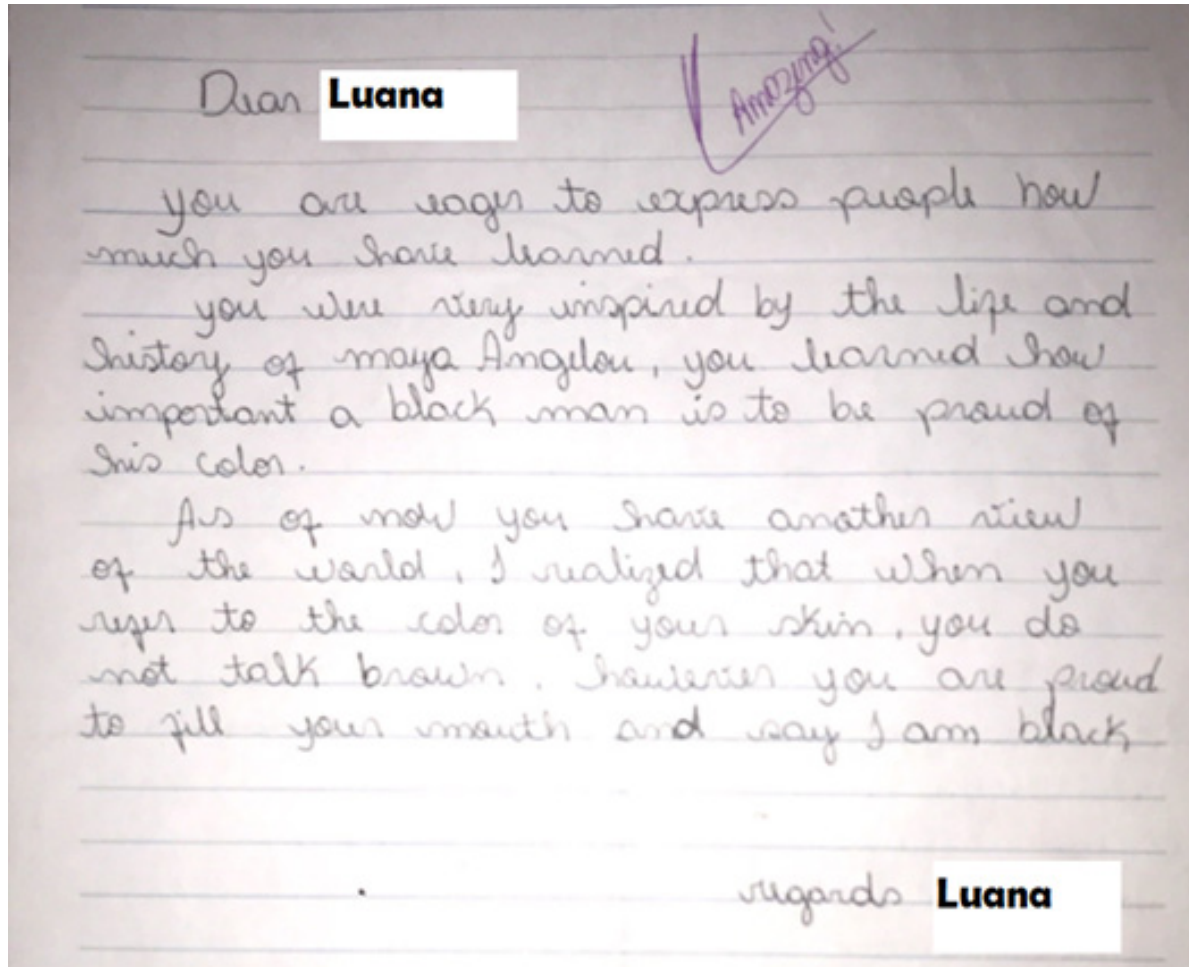

Figure 2. Luana's letter to herself regarding the classes about Maya Angelou

Dear Luana,

You are eager to express people how much you have learned.

You were very inspired by the life and history of Maya Angelou, you learned how important a black man is to be proud of his color. As of now you have another view of the world, I realized that when you refer to the color of your skin, you do not talk brown. However you are proud to fill your mouth and say I am black.

Regards, Luana.

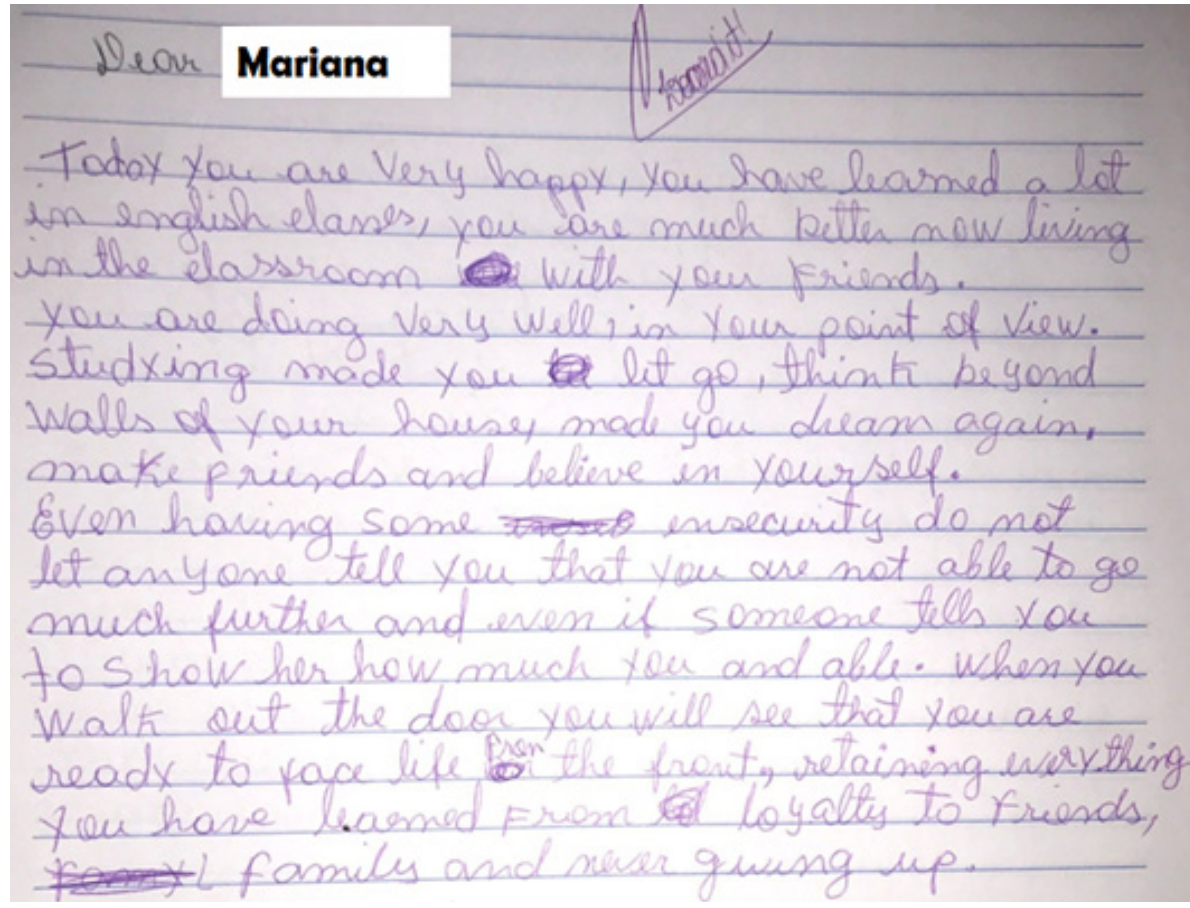

Figure 3. Mariana's letter to herself regarding the classes about Maya Angelou

Dear Mariana

Today you are happy, you have learned a lot in English classes, you are much better now living in the classroom with your friends. You are doing very well in your point of view. Studying made you let go, think beyond walls of your house, made you dream again, make friends and believe in yourself. 
Even having some insecurity do not let anyone tell you that you are not able to go much further and even if someone tells you to show her how much you and able. When you walk out of the door you will see that you are ready to face life from the front, retaining everything you have learned from loyalty to friends, family and never giving up.

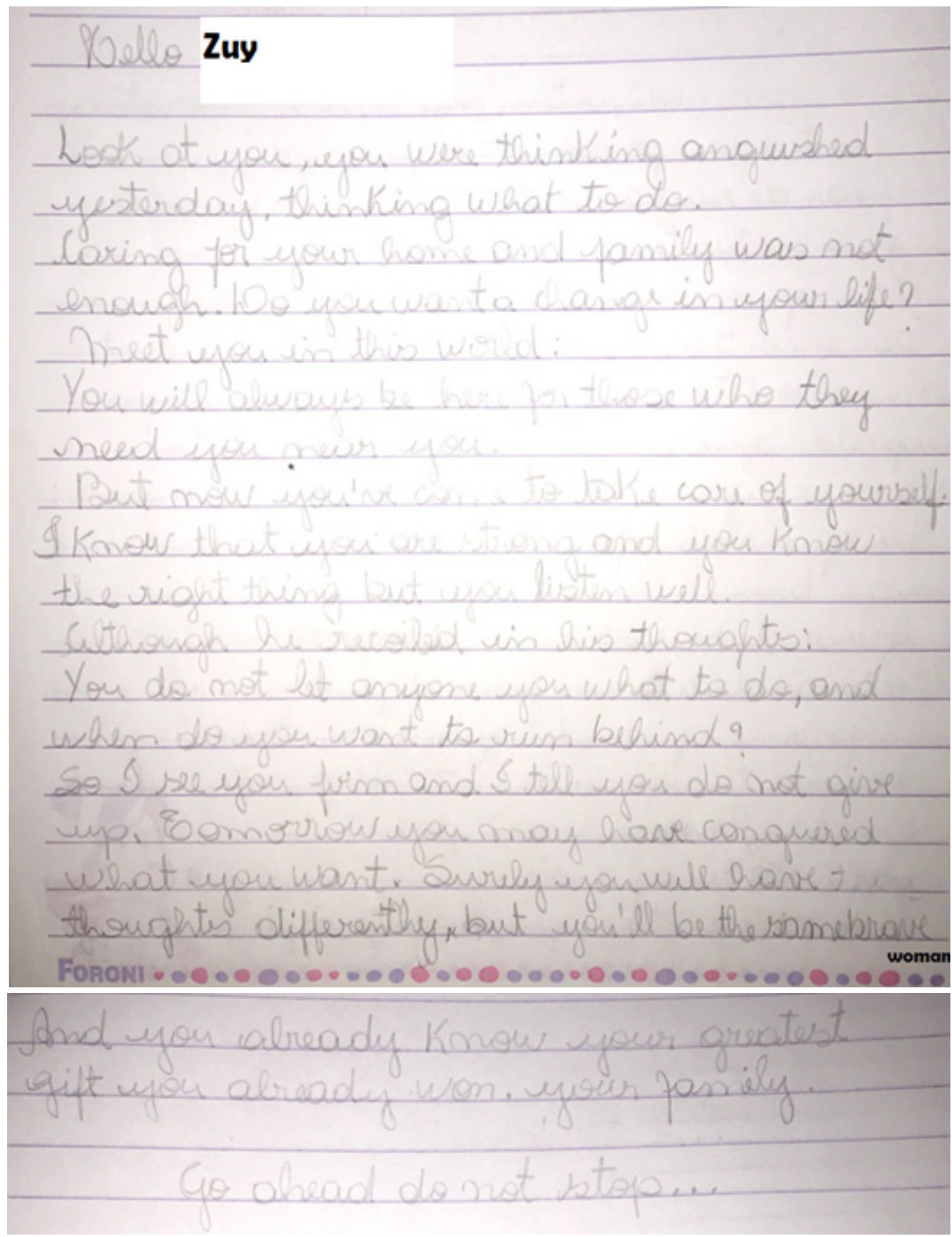

Figura 4. Zuy's letter to herself regarding the classes about Maya Angelou

Hello Zuy,

Look at you, you were thinking anguished yesterday. Thinking what to do.

Caring for your home and family was not enough. Do you want a change in your life?

Meet you in this world:

You will always be here for those who they need you near you.

But now you've come to take care of yourself.

I know that you are strong and you know the right thing but you listen well.

Although he recoiled in this thoughts:

You do not let anyone you what to do, and when do you want to run behind?

So I see you firm and I tell you do not give up. Tomorrow you may have conquered what you want. Surely you will have thoughts differently, but you'll be the same brave woman.

And you already know your greatest gift you already won. Your family.

Go ahead do not stop...

For this part of the analysis, we opted to group the four participants' excerpts, considering that all of them equally contribute to a broader view of what the English classes about Maya Angelou meant to each one of them. Concerning collaboration, Luana mentions she is eager to share with other people what she learned in class. Similarly, Mariana contends that she also has learned in class and that the bonds with her classmates have been strengthened. 
As Scarcella and Oxford highlight (1992), some of the benefits of working together in classroom are increased confidence, higher self-esteem and increased altruism, aspects which have been considered by Luana and Mariana in their letters.

Regarding English language learning, Angel claims she has learned many new words that have enriched her vocabulary. The student also argues that Maya Angelou used the words to fight for the blacks' rights and to teach other people how to achieve their goals. Angel's statement demonstrates that, regardless of her English proficiency level, she could grasp the teacher's previous suggestion that collaboration is intrinsically related to critical learning.

With respect to critical language learning, the four letters provide evidence of how these students were able to link our discussions with broader aspects, such as race/racism and social class, as well as relate them to their own narratives (PENNYCOOK, 2001). Furthermore, they did it in a way they engaged with questions of race, power, and inequality, "problematizing how language perpetuates inequitable social relations" (PESSOA, 2014, p. 357).

Luana's letter illustrates how important those classes were to her since she used to escape from her black identity. The journey with Maya Angelou and with her classmates, and everything she has experienced in life made her realize "how important it is for a black person to be proud of his/her color". This may be one of the reasons she is glad to open her mouth now and say: "I am black", which seems to be her disclaimer to the "construction and naturalization of languages as bounded and separate objects associated with particular racial groups" (ROSA; FLORES, 2017, p. 623).

In Mariana's letter, it is also possible to perceive how meaningful our journey was to her personal life. When she pointed out that the classes allowed her to think beyond the walls of her house, the teacher promptly understood that learning English through the stories of subaltern bodies - just like Maya Angelou's black body - is a possibility to enable people to believe in themselves again. In actuality, it was as an alternative that helped them realize that these bodies, most times quite similar to theirs, exist and that they can be redescribed from different perspectives.

Finally, Zuy's letter caught our attention because it was not just a reflection on the English lessons; she problematized and wrote about her own life. Additionally, the teacher recalls seeing her crying outside the classroom when she was challenged to write a letter to herself. She was touched by that task because it was a wake-up call to her. More than simply doing classwork, she felt like she had been invited to rethink her attitudes towards herself and her family. As put by Silvestre (2017, p. 96-97), "self-reflexivity is one of the items that has to be taken into account to know if something is critical or not [...], especially if we think of an academic-professional concept of critique". Hence, Zuy's and the other students' letters illustrate one of the most important concepts of critical language learning: self-reflexivity.

\section{THANK YOU FOR THE (UN)LEARNING EXPERIENCE}

We end this paper by showing our gratitude to all the people who participated in this journey with us. This investigation may open new paths so that other researchers and non-academic people can explore and understand collaboration and critical English language learning in a different fashion. First, it demonstrated that one goes hand in hand with the other. Second, it proved that working critically and collaboratively does not depend on students' proficiency level. Third, it illustrated that it is possible to have YAE students learn English and engage them in broader discussions. Finally, yet importantly, this study showed that it is possible to have students bring the topics discussed in class close to their personal lives, especially through the use of letters.

Yet, it is imperative to underscore that none of this would have been possible without the help of the woman who inspired us along the way. Maya Angelou's life stories were the source of strength and courage we needed to look at our lives and at language education through English differently. Through her experiences, we could re-examine ours and learn more about the English language.Tilio (2013) contends that affiliating with the critical perspectives does not despise the work with grammar, listening, writing, speaking, and other skills. On the contrary, this approach extends these skills to a broader social stance trying to make the learning experience truly a social practice. Hence, we do not deny the importance of working with these skills provided that they are problematized and critically applied in class.

Even though there were several achievements already mentioned here, some obstacles also became part of our journey: unfortunately, the teacher could not engage the whole class with him in this trip from beginning to end since 
other fellow students had different schedules that did not allow them to follow the proposed itinerary; and although both the teacher and the students attempted to problematize and collaborate with each other throughout the whole process, we sometimes found ourselves alone and stuck in our own convictions. Perhaps this is part of our journey here.

Finally, it is important to mention that we achieved our goal. We were able to discuss the biography of Maya Angelou and intertwine her life experiences with a collaborative and critical approach to the learning of English. As narrated in the course of this trip, we got here by reflecting upon our bodies, our families, our friends, our skin colour, our own language, and ourselves, crying sometimes and laughing most of the time. All this inspired by and because of the story of an African-American woman named Maya Angelou.

\section{REFERENCES}

ALMEIDA, R. R. (2017). Educação linguística crítica de aprendizes de inglês: problematizações e desestabilizações. 2017. Dissertação (Mestrado Interdisciplinar em Educação, Linguagem e Tecnologia) - Universidade Estadual de Goiás, Anápolis.

ANDRÉ, M. E. D. A. (1995). Etnografia da prática escolar. Campinas: Papirus.

CRANDALL, J. J. (1999). Cooperative language learning and affective factors. In: ARNOLD, J. (ed.). Affect in language learning. Cambridge: Cambridge University Press: 226-245.

FIGUEIREDO, F. J. Q. (2008). The influences of collaboration on the learning of a foreign language. MOARA, 30: 117-134.

FIGUEIREDO, F. J. Q. (2018). A aprendizagem colaborativa de línguas: considerações conceituais e aplicações em distintos contextos. In: FIGUEIREDO, F. J. Q. (org.). A aprendizagem colaborativa de línguas. 2. ed. rev. e ampl. - Goiânia: Editora UFG: $13-57$.

FIGUEIREDO, F. J. Q.; LAGO, N. A. (2018). O que eu sinto e como reajo: a autoestima e a atitude quanto à escrita na revisão colaborativa. In: FIGUEIREDO, F. J. Q. (org.). A aprendizagem colaborativa de linguas. 2. ed. rev. e ampl. - Goiânia: Editora UFG: 195-234.

GHAITH, G. M. (2002). The relationship between cooperative learning, perception of social support, and academic achievement. System, 30: 263-273.

HOELZLE, M. J. L. R. (2016). Desestabilizando sociabilidades em uma sala de aula de Língua Inglesa de uma escola pública. Dissertação (Mestrado em Letras e Linguística). Faculdade de Letras, Universidade Federal de Goiás, Goiânia.

LAGO, N. A.; CINTRA, D. N. M. (2016). 'Sou uma pessoa melhor': formação continuada de professores de inglês. In: PESSOA, R. R.; OLIVEIRA, E. C. Tensões e desestabilizações na formação de professoras/es de inglês. Goiânia: Ed. UFG: 133-155.

MAGALHÃES, M. C. C. (2014). Escolhas teórico-metodológicas em pesquisas com formação de professores: as relações colaborativo-críticas na constituição de educadores. In: MATEUS, E.; OLIVEIRA, N. B. (org.). Estudos Críticos da Linguagem e Formação de Professores/as de Linguas: Contribuições Teórico-Metodológicas. Campinas, SP: Pontes Editores: 17-47.

MOITA LOPES, L. P. (2006). Uma linguística aplicada mestiça e ideológica: interrogando o campo como linguista aplicado. In: MOITA LOPES, L. P. (org.). Por uma Linguística Aplicada Indisciplinar. São Paulo: Parábola Editorial: 13-44.

MORRISON, T. (1975). Black Studies Center Public Dialogue. Pt. 2. Toni Morrison at Portland State. From Portland State University's Oregon Public Speakers Collection. Online: http://mackenzian.com/wpcontent/uploads/2014/07/Transcript_ PortlandState_TMorrison.pdf. Accessed: July 18, 2019.

O'DONNEL, A.M.; DANSEREAU, D.F. (1992). Scripted cooperation in students' dyads: A method of analyzing and enhancing academic learning and performance. In: HERTZ-LAZAROWITZ, R.; MILLER, N. (ed.). Interaction in cooperative groups: the theoretical anatomy of group learning. Cambridge: Cambridge University Press: 120-144.

OKAZAKI, T. (2005). Critical consciousness and critical language teaching. Second language studies, 23(2): 174-202. 
PENNYCOOK. A. (2001). Critical Applied Linguistics: a critical introduction. Mahwah, NJ: Lawrence Erlbaum Associates.

PENNYCOOK, A. (2004). Critical moments in a TESOL praxicum. In: NORTON, B.; TOOHEY, K. (org.). Critical pedagogies and language learning. Cambridge: CUP: 27-345.

PENNYCOOK, A. (2012). Language and mobility. Unexpected places. Bristol: Multilingual Matters.

PESSOA, R. R. (2014). A critical approach to the teaching of English: pedagogical and identity engagement. Revista Brasileira de Linguística Aplicada, 14(2): 353-372.

ROSA, J.; FLORES, N. (2017). Unsettling race and language: Toward a raciolinguistic perspective. Language and Society, 46(5): 621-647.

SABOTA, B. (2017). Leitura e Compreensão Textual. In: FIGUEIREDO, F. J. Q. (org.). Formação de professores de línguas estrangeiras: princípios e práticas. 2. ed. rev. e ampl. - Goiânia: Editora UFG: 125-150.

SABOTA, B. (2018). Traçando os fios da leitura em língua inglesa: por uma resolução colaborativa de exercícios de compreensão textual. In: FIGUEIREDO, F. J. Q. (org.). A aprendizagem colaborativa de línguas. 2. ed. rev. e ampl. - Goiânia: Editora UFG: 99-131.

SCARCELLA, R. C.; OXFORD, R. L. (1992). The Tapestry of Language Learning. Boston: Heinle \& Heinle Publishers.

SILVESTRE, V. P. V. (2017). Colaboração e crítica na formação de professores/as de línguas: teorizações construídas em uma experiência com o Pibid. 1. ed. Campinas, SP: Pontes Editores.

SOUSA, L. P. Q.; TIRABOSCHI, F. F.; LAGO, N. A.; FIGUEIREDO, F. J. Q. (2019). Collaborative English language learning: some reflections from interactions between pairs. Trabalbos em Linguística Aplicada, 58(1): 259-286.

TILIO, R. C. (2013). Repensando a abordagem comunicativa: multiltramentos em uma abordagem consciente e conscientizadora. In: ROCHA, C. H.; MACIEL, R. F. (org.). Lingua estrangeira e formação cidadã: por entre discursos e práticas. 2ed. Campinas: Pontes, v. 1: 51-67.

URZÊEDA-FREITAS, M. T. (2012). Pedagogia como transgressão: problematizando a experiência de professores/as de inglês com o ensino crítico de línguas. 2012. 245f. Dissertação (Mestrado em Letras e Linguística: Estudos Linguísticos). Faculdade de Letras, Universidade Federal de Goiás, Goiânia.

URZÊEDA-FREITAS, M. T. (2018). Letramentos queer na formação de professorxs de línguas: complicando e subvertendo identidades no fazer docente. 2018. 285f. Tese (Doutorado em Letras e Linguística). Faculdade de Letras, Universidade Federal de Goiás, Goiânia.

VASQUES, C. C.; ANJOS, M. B.; SOUZA, V. L. G. (2019). Políticas públicas para a Educação de Jovens e Adultos (EJA). Revista Educação Pública, 19(16). Online: < https://educacaopublica.cecierj.edu.br/artigos/19/16/politicas-publicaspara-a-educacao-de-jovens-e-adultos-eja > Accessed: October 17, 2021.

Recebido: 24/2/2021

Aceito: 16/10/2021

Publicado: 27/10/2021 